\title{
Analyzing Anomalous Topographic Map Drainage System and Landform Evidence as a Glacial History Paradigm Problem: A Literature Review
}

\author{
Eric Clausen \\ Independent Researcher, 100 West Ave D-17, Jenkintown, PA, USA \\ Email: eric2clausen@gmail.com
}

How to cite this paper: Clausen, E. (2020) Analyzing Anomalous Topographic Map Drainage System and Landform Evidence as a Glacial History Paradigm Problem: A Literature Review. Open Journal of Geology, 10, 1072-1090.

https://doi.org/10.4236/ojg.2020.1011052

Received: October 23, 2020

Accepted: November 24, 2020

Published: November 27, 2020

Copyright $\odot 2020$ by author(s) and Scientific Research Publishing Inc. This work is licensed under the Creative Commons Attribution International License (CC BY 4.0).

http://creativecommons.org/licenses/by/4.0/

(c) (i) Open Access

\begin{abstract}
While not usually stated, detailed topographic maps show well-mapped anomalous drainage system and other erosional landform evidence the accepted North American Cenozoic geologic and glacial history paradigm (accepted paradigm) does not permit geomorphologists to satisfactorily explain. A new and fundamentally different paradigm able to explain the drainage system and other erosional landform evidence has recently emerged, but requires what the accepted paradigm considers to be the preglacial (and probably mid-Cenozoic) Bell River drainage system to have formed on a melting continental ice sheet's floor. The new paradigm's melting ice sheet had previously eroded bedrock underneath it and caused crustal warping that raised continental regions and mountain ranges so as to create and occupy a deep "hole" while massive and prolonged meltwater floods flowed across rising continental regions and mountain ranges to the south. The new paradigm leads to a completely different middle Cenozoic geologic and glacial history than the accepted paradigm describes and the two paradigms are analyzed according to good science expectations such as using evidence anyone can see, applying common sense logic during each research step, producing consistent results, and simplicity of paradigm generated explanations. The new paradigm uses topographic map evidence anyone can see, appears to use common sense logic during each research step, and produces remarkably consistent results leading to a simpler Cenozoic northern Missouri River drainage basin region geologic and glacial history than what the accepted paradigm describes. Further work is needed to test the new paradigm's ability to explain drainage system and erosional landform evidence in other geographic regions such as in the Ohio River drainage basin.
\end{abstract}




\section{Keywords}

Bell River Drainage System, Geomorphology, Missouri River Drainage Basin, Northern Great Plains, Rocky Mountains

\section{Introduction: The Anomalous Evidence Problem}

Even though excellent detailed topographic maps exist, most modern-day United States geomorphologists avoid using those maps to do regional drainage history research. This was not always the case as early literature summaries like the Fenneman [1] [2] "Physiography of the Western United States" and "Physiography of Eastern United States" and Thornbury [3] "Regional Geomorphology of the United States" identify hundreds of regional drainage history studies (which relied on detailed topographic maps), yet since the mid $20^{\text {th }}$ century similar regional drainage history studies have rarely been published. Did geomorphologists answer all possible regional drainage history questions? No, instead geomorphologists could not provide satisfactory answers for many of their regional drainage history questions and by the mid- $20^{\text {th }}$ century (in spite of expanding topographic map coverage) most geomorphologists gave up on trying to use topographic maps to answer regional drainage history questions. Arthur Strahler, for example, was trained to do regional drainage history research, but after failing to advance the study of Pennsylvania stream development (described in a 1945 paper [4]), he abandoned such drainage system origin studies and turned instead to developing what he called the dynamic basis of geomorphology [5]. However, in some of the last classes Strahler taught at Columbia University (in which Clausen, the author of this paper, was a student), considerable time was spent discussing still unanswered regional drainage history questions.

Regional drainage history research requires the interpretation of drainage system and other erosional landform evidence (often best observed on detailed topographic maps) the accepted Cenozoic geologic and glacial history paradigm (accepted paradigm) does not satisfactorily explain, and why would competent researchers waste time trying to solve unsolvable problems? Strahler, like many other geomorphologists of his time, was a skilled topographic map interpreter and almost every new topographic map the United States Geological Survey (USGS) published showed intriguing new and unexplained drainage features and other erosional landforms. While the topographic map evidence could usually be interpreted to tell a story, unfortunately those stories frequently were significantly different from the accepted paradigm's geologic and glacial history story. Paradigms according to Kuhn [6] by themselves are neither correct nor incorrect, but are rules and interpretations determining how a scientific discipline governs its research and are selected based on their ability to explain evidence and to open up new research opportunities. While perhaps successful for 
some geology subdisciplines, the accepted paradigm led geomorphologists to a solid wall of well-mapped anomalous detailed topographic map drainage system and erosional landform evidence.

According to Kuhn a scientific discipline when faced with anomalous evidence can do one of three things. First, the anomalous evidence can be identified and catalogued (or mapped) and set aside in the hope some future scientist will explain it, which is what did happen with the anomalous topographic map drainage system and erosional landform evidence. Second, the discipline's accepted paradigm can be modified to eventually explain the anomalous evidence and then continue without any serious interruption, however in this case the anomalous topographic map evidence has been known for at least 60 years and almost all geomorphologists have given up on trying to explain it. Third, a new paradigm able to explain the anomalous evidence may emerge and a battle over which paradigm to use will begin. During such paradigm wars Kuhn advises against using one paradigm to judge the other, but instead suggests determining which paradigm best explains the evidence and offers the most attractive new research opportunities.

The author of this paper (Clausen) has recently published demonstration papers illustrating how a new and fundamentally different paradigm explains the detailed topographic map evidence. These demonstration papers (several of which this literature review cites) address detailed topographic map evidence in specific northern Missouri River drainage basin geographic localities and illustrate how the new paradigm leads to a completely different Cenozoic geologic and glacial history than what the accepted paradigm describes. Based on published demonstration papers this paper describes new paradigm requirements and how those requirements explain northern Missouri River drainage basin geologic and glacial history. From the accepted paradigm perspective some new paradigm requirements are improbable and impossible, but Kuhn argues one paradigm should not judge the other. Instead, the competing paradigms are here judged independently based on science research expectations related to each paradigm's ability to explain actual evidence and to open up new research opportunities. Those science research expectations require evidence to be observable by anyone willing to look, common sense logic to be used during each of the research process steps, all interpretations of evidence to be consistent with each other, and where two or more possible explanations exist Occam's Razor to be used to determine which of the alternate paradigms leads to the simplest explanations (or the explanations requiring the fewest assumptions).

\section{The Bell River Drainage System Relative Age Problem}

The accepted North American Cenozoic geologic history paradigm describes the Missouri River in South and North Dakota and eastern Montana (see Figure 1) to have been formed when a continental ice sheet blocked north-oriented drainage routes leading to a preglacial drainage system named as the Bell River 


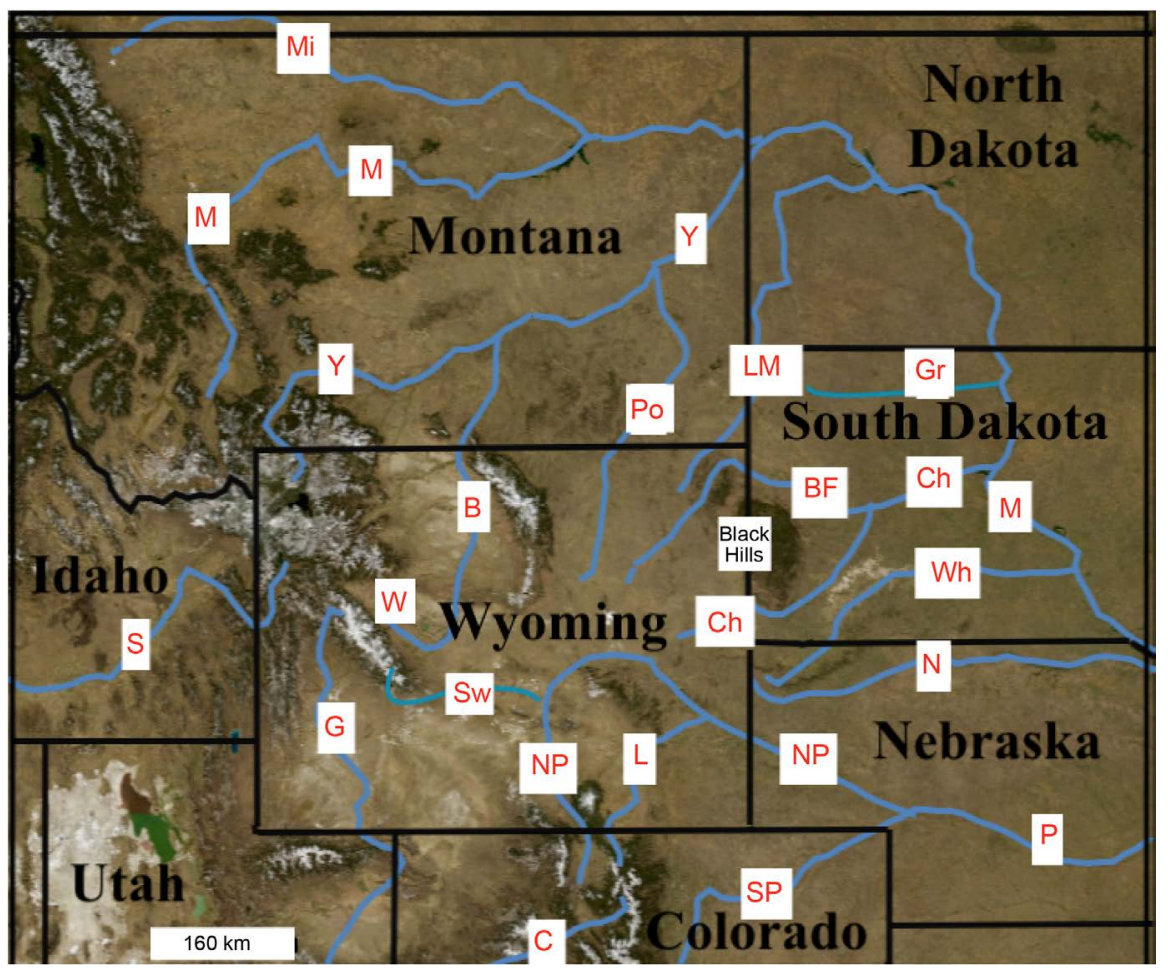

Figure 1. Modified United States Geological Survey national map website imagery location map with letters designating major rivers as identified in the text.

drainage system. Today, long north-, northeast-, and east-oriented tributaries (including the north-oriented Missouri River headwaters) join the Missouri River in eastern Montana and western North and South Dakota and abandoned valleys (now partially filled by glacially deposited debris) extend northward and northeastward from the Missouri River valley. The abandoned valleys can be traced off and on northward across Canada to the Hudson Bay region and Labrador Sea (see McMillan [7] and Duk-Rodkin and Hughes [8]). Jackson [9] in a general audience article describes the Bell River drainage system and includes a discussion of a Sears [10] hypothesis that the Colorado River during Miocene time made a turn in the Grand Canyon area to flow in a north direction so as to join the Bell River drainage system. White [11] [12] argued deep continental ice sheet erosion should have destroyed those partially buried "pre-glacial" valleys, but Gravenor [13], Sugden [14], and other glacial geologists disagreed and almost all glacial geologists have since ignored White's warning.

Figure 1 illustrates areas where most published new paradigm related research has been concentrated and identifies major rivers by letters as follows: B-Big Horn, BF-Belle Fourche, C-Colorado, Ch-Cheyenne, G-Green, Gr-Grand, L-Laramie, LM-Little Missouri, M-Missouri, Mi-Milk, N-Niobrara, NP-North Platte, P-Platte, Po-Powder, S-Snake, Sw-Sweetwater, W-Wind, Wh-White, and Y-Yellowstone. The accepted paradigm considers the asymmetric Missouri River drainage basin seen in South and North Dakota and eastern Montana to have formed when a continental ice sheet blocked north- and northeast-oriented 
drainage routes to the pre-glacial Bell River drainage system including the north-oriented Missouri River headwaters, Yellowstone River and its north-oriented Bighorn and Powder River tributaries, Little Missouri River, and Cheyenne River with its Belle Fourche River tributary (not shown are other South and North Dakota and eastern Montana north- and northeast-oriented Missouri River tributaries). There has been disagreement about where to put the pre-glacial north-south drainage divide with some workers putting it between the Cheyenne and White Rivers and others between the White River and Niobrara River. In South and North Dakota coarse-grained glacial erratic material can be found several tens of kilometers to the west and south of the Missouri River, with finer-grained glacial tills abundant to the east and north of the Missouri River.

A pre-glacial age for the north- and northeast-oriented Missouri River tributaries creates a serious problem for geomorphologists seeking to interpret western South and North Dakota, eastern Montana, and northeastern Wyoming topographic map evidence. Detailed topographic maps show aligned northwestand southeast-oriented tributaries to most of the larger and longer north- and northeast-oriented Missouri River tributaries. The aligned northwest- and southeast-oriented secondary drainage routes have intrigued geomorphologists since detailed topographic maps of the region became available. Aligned drainage areas are most common in the area south and west of the Missouri River valley and drain to the north- and northeast-oriented Missouri River tributaries that according to the accepted paradigm flowed to the preglacial Bell River drainage system and predate North American (Cenozoic) continental ice sheets. As a result, geomorphologists such as Russell [15] and White [16] tried to develop somewhat complicated hypotheses attributing the aligned drainage to the prevailing wind directions although other workers including Shurr [17] tried to associate aligned drainage orientations with subsurface lineaments. In any case, no consensus has ever been reached and the regional aligned drainage remains a well-known, but poorly explained geomorphic feature.

Further complicating topographic map interpretation in western South and North Dakota is a zone of only coarse-grained glacial erratic materials which extends several tens of kilometers to the south and west of the Missouri River valley (which marks the southern and western limit of the finer-grained glacial deposits). This glacial erratic zone is well known and is shown on the Geologic Map of North Dakota [18] and is discussed by Flint [19] who studied South Dakota glacial deposits and who determined glacial erratic boulders on both sides of the Missouri River show the same amount of weathering. For this reason, Flint developed a complicated hypothesis to explain how the same continental ice sheet could deposit fine- and coarse-grained materials north and east of the Missouri River and only coarse-grained erratic material south and west of the Missouri River. Whatever the explanation the zone of coarse-grained erratic cobbles and boulders indicates a continental ice sheet once extended tens of ki- 
lometers south and west of the North and South Dakota Missouri River valley and common sense logic says, if the accepted paradigm interpretation is correct, the ice-marginal Missouri River valley should be located along the coarse-grained glacial erratic outer margin and not some tens of kilometers to the north and east. Yet detailed topographic maps show no convincing evidence a large ice marginal river valley ever developed along the glacial erratic outer margin and several north- and northeast-oriented Missouri River tributary valleys now extend across the coarse-grained glacial erratic zone as though no ice sheet had ever been present.

What the detailed topographic maps do show are numerous shallow low points along drainage divides between north- and northeast-oriented Missouri River tributaries in the western Dakotas and eastern Montana that link the aligned northwest- and southeast-oriented tributaries and also that the northand northeast-oriented Missouri River tributary valleys were formed in an identifiable sequence (from southeast to northwest). This evidence is discussed and illustrated in several new paradigm demonstration papers including [20] and [21]. While map evidence suggests north- and northeast-oriented Missouri River tributary valleys eroded headward in sequence across large southeast-oriented ice-marginal floods that interpretation from the accepted paradigm perspective is impossible because the north- and northeast-oriented valleys already existed prior to any continental ice sheets and even if continental ice sheet melt water had eroded the north- and northeast-oriented valleys, the north- and northeast-oriented valleys would have had to erode headward from the continental ice sheet location and also because some north- and northeast-oriented valleys (and the low points along drainage divides linking the northwest- and southeast-oriented secondary drainage routes) continue headward into the much higher elevation Rocky Mountain region. There is no accepted paradigm mechanism able to explain why valleys could have eroded headward from a continental ice sheet location and then headward into high elevation areas, which is one of the many reasons why the detailed topographic map evidence drainage system and erosional landform evidence cannot be satisfactorily explained.

\section{New Paradigm Summary}

The new paradigm explains how north- and northeast-oriented valleys eroded headward from a continental ice sheet location and then headward high into the Rocky Mountains by requiring a thick North American continental ice sheet (located where continental ice sheets are usually mapped to have been) that eroded underlying bedrock and which through crustal warping raised surrounding regions and mountain ranges to create and occupy a deep "hole" while immense and prolonged meltwater floods flowed across the rising regions and mountain ranges. Diversion of massive south-oriented ice-marginal meltwater floods to the continental ice sheet location indicates ice-marginal floods flowed at elevations much higher than the ice sheet floor and that ice sheet melting 
opened up deep "hole" space into which the floods could flow. A new paradigm demonstration paper [22] describes how diverted floods flowed into an ice-walled canyon network as the ice sheet melted with poorly explained Northern Plains erosional escarpments (such as the 1000-kilometer long Missouri Escarpment) being an ice-walled canyon wall remnant (the Missouri Escarpment is a 100- to 200-meter high step from higher plains to the west and south to lower plains to the east and north and in South and North Dakota is roughly 50- to 100-kilometers east and northeast of the paralleling Missouri River and a zone of thick ice stagnation debris known as the Missouri Coteau is located between the escarpment and the Missouri River). Rather than having a preglacial age as the accepted paradigm requires, the new paradigm requires the Bell River system valleys to have formed on a melting ice sheet's floor. In addition, the new paradigm suggests the north-oriented floods froze in the ice-walled canyons so as to create a second and much thinner ice sheet consisting of first ice sheet remnants and frozen floodwaters, which explains the partially filled (with glacial debris) north-oriented Bell River system valleys (and the Missouri River formed along the second ice sheet's southwest margin).

The northern Missouri River drainage system is located on a northeast-oriented slope and while the accepted paradigm requires that slope to have formed during pre-glacial time the new paradigm requires the northeast-oriented slope to have been formed by a combination of ice sheet erosion and ice sheet related crustal warping and also requires northeast slope development to have gradually diverted the immense and prolonged south- and southeast-oriented meltwater floods to flow in new directions. Such an interpretation means the Montana, Wyoming, and northern Colorado east-west continental divide formed as a segment of the ice sheet created deep "hole" southwest rim while massive and prolonged meltwater floods flowed across and along that deep "hole" rim, which explains numerous previously unexplained mountain passes along that and other continental divide segments. For example, another new paradigm demonstration paper [23] illustrates how large south-oriented floods moving from what is now the north-oriented North Platte River headwaters area eroded mountain passes now crossing the Colorado east-west continental divide as the floodwaters first moved to southeast- and east-oriented South Platte River headwaters before being captured by headward erosion of the south- and southwest-oriented Colorado River valley (before regional and mountain uplift reversed the flood flow to create what are now north-oriented North Platte River headwaters drainage routes). Still another demonstration paper [24] describes how north-oriented tributary drainage routes (beginning today as south-oriented streams) record how Sweetwater River valley headward erosion along the deep "hole's" southwest rim beheaded and reversed south-oriented flood flow channels that had been moving large volumes of water to and across what is now Wyoming's Great Divide Basin.

By linking regional and mountain uplift to a thick continental ice sheet's 
presence the new paradigm becomes a powerful tool providing remarkably precise explanations for much if not all of the northern Missouri River drainage basin drainage system and other erosional landform topographic map evidence. For example, one of the new paradigm demonstration papers [25] describes how large and prolonged southeast-oriented floods carved a previously unexplained complex of diverging and converging valleys into an emerging South Dakota Black Hills upland while another new paradigm demonstration paper [26] describes how headward erosion of the northeast-oriented Cheyenne River valley (to the east of the Black Hills) captured the massive southeast-oriented floods and left the large Sage Creek and Scenic Basins as abandoned southeast-oriented flood-formed headcuts and still another new paradigm demonstration paper [27] shows how massive southeast-oriented floods flowed across the Powder River Basin (to the west of the Black Hills). Evidence for Cheyenne River capture of southeast-oriented streams was previously described from the accepted paradigm perspective by several workers including Todd [28] and Harksen [29], who discussed alluvium from a powerful river that flowed from the central Black Hills onto the Great Plains, and more recently Zaprowski et al. [30] and Stamm et al. [31] who used ash dates obtained by Stafflin [32] to suggest the captures took place after about $660 \mathrm{ka}$, although these and other previous workers did not address why and how Cheyenne River valley headward erosion was able to capture multiple southeast-oriented streams, or explain the obvious diverging and converging abandoned valley complex crossing what is now the highest Black Hills drainage divide (evidence easily observed on detailed topographic maps).

At this point in its development the new paradigm's greatest strength is its ability to explain topographic map drainage system evidence such as drainage divides, barbed tributaries, abrupt drainage route directions changes, asymmetric drainage divides, mountain passes and similar erosional landform features. Another new paradigm demonstration paper [33] describes how headward erosion of the north-oriented Little Missouri River and Boxelder and Little Beaver Creek valleys (north-oriented Little Missouri tributaries) in northwest South Dakota and southeast Montana (where the red LM in Figure 1 is located) across southeast-oriented flood flow channels moving floodwaters to the east-oriented Grand River headwaters, and explains mapped barbed tributaries, asymmetric drainage divides between north- and northeast-oriented drainage routes, and the Jump-Off escarpment-surrounded basin (the new paradigm interprets large escarpment-surrounded basins as flood formed features while investigators following accepted paradigm rules frequently attribute these escarpment-surrounded basins to spring sapping). Interestingly in that same northwest South Dakota geographic region Toepelman [34] in his $\mathrm{PhD}$ thesis (supervised by J Harlen Bretz) described large landslide blocks at Reva Gap along walls of what he interpreted to have been a deep northwest-to-southeast oriented canyon and Gill [35] mapped landslide blocks along what he interpreted to be northwest-to-southeast oriented canyons at Reva Gap and at several other nearby localities, although 
Lillegraven [36] reported finding no evidence a river had flowed through the region and attributed the tilted sedimentary blocks to subsurface faulting. Supporting the Toepelman and Gill interpretations Clausen [37] found rounded cobbles and small boulders associated with all of the Toepelman and Gill mapped landslide blocks.

Except for changing the Bell River drainage system formation relative age position from pre-glacial (possibly middle Cenozoic) to late during the first (Cenozoic) North American continental ice sheet's melt history the new paradigm does not change previously determined relative ages, but probably requires meltwater floods to have deposited many Oligocene, Miocene, and Pliocene sediments and possibly even some Eocene sediments. As mentioned, the first new paradigm continental ice sheet was heavy, meaning it was several kilometers thick and when fully developed it stood higher than any present-day North American mountain ranges (even after the crust underneath it had subsided and the ice sheet had deeply eroded the underlying bedrock). Like in high mountain ranges today climatic conditions on the ice sheet high elevation surface would have been much different than at the ice sheet's base and elsewhere on the continent. The ice sheet presence probably created high precipitation especially along ice sheet margins where snow fell in high elevation ice sheet areas and rain fell in what were more temperate and even warm adjoining non-glaciated regions. These contrasting climatic conditions probably resulted in a situation where every summer massive melting occurred along ice sheet margins which was balanced by new snow accumulations and by the ice sheet's constant outward flow. It is not known how long in terms of absolute time these conditions continued, but based on the amount of new paradigm required regional and mountain range uplift and melt water erosion the absolute time period must have been significant.

The new paradigm recognizes a North American Cenozoic glacial history consisting of two linked continental ice sheets with the first and probably longer-lived thick ice sheet creating and occupying a deep "hole." Most of North America's present-day topographic relief, drainage systems, and larger scale erosional landforms developed during the first ice sheet's history and for that reason, existing drainage systems and erosional landforms cannot be used to determine the first ice sheet's early history, other than to say the ice sheet formed on what may have been a low relief North American surface that looked very different from the continent's surface today and with sedimentary rocks probably covering the Canadian Shield and many if not all of what are now mountain range areas where Precambrian bedrock is now exposed. The first thick ice sheet depressed the crust underneath it, which caused crustal warping that gradually raised mountain ranges and entire regions and which produced immense (seasonal?) south-oriented meltwater floods. The first ice sheet contained the equivalent of an ocean of frozen water, which was constantly being replenished. That first ice sheet and its meltwater floods existed long enough for the ice sheet re- 
lated crustal warping to raise today's mountain ranges, plateaus, and other higher elevation areas which, until their uplift blocked and diverted the south-oriented meltwater flood flow, were being eroded by the huge meltwater floods that flowed across them. Eventually the first ice sheet decayed with even larger quantities of meltwater flowing from it and then toward it and at this point topographic maps can identify many meltwater flood flow routes and how those melt water floods were systematically diverted to flow onto and across the decaying ice sheet's floor.

Poorly explained (by the accepted paradigm) North American glaciated prairie region erosional escarpments are remnants of ice-walled and bedrock-floored canyons formed as giant supra-glacial meltwater rivers sliced into the decaying ice sheet to create a series of smaller and detached ice sheet masses. The Missouri Escarpment formed as the southwest and west wall of one such ice-walled and bedrock-floored canyon which detached much of the first ice sheet's southwest margin and from which the western Dakota and eastern Montana northeast- and north-oriented Missouri River tributary valleys eroded headward to capture large ice-marginal floods while other erosional escarpments record how other ice-walled and bedrock-floored canyons cut the decaying ice sheet into smaller ice sheet masses. Diverted ice-marginal floods once in the ice-walled canyon network first flowed in south directions to the lower Missouri River valley (downstream from Yankton, SD) and to the Mississippi River (downstream from St. Paul, MN), but as ice sheet melting continued the flow was systematically diverted to the Gulf of St. Lawrence and then further north by capture events many of which present-day river direction changes and erosional escarpments record. Diversion of the ice-marginal floods from the Gulf of Mexico to the North Atlantic radically changed climatic conditions so as to freeze the diverted ice-marginal floods and other north-oriented drainage between the decaying first ice sheet remnants and created a second and much thinner ice sheet and which also led to glaciation in the then newly uplifted mountain ranges. The Missouri River formed along the second ice sheet margin and the North and South Dakota zone of coarse-grained glacial erratic material to the south and west of the Missouri River is where earlier ice-marginal floods had eaten into the first ice sheet's southwest margin. The second ice sheet did not deeply erode and eventually melted perhaps in ways perhaps similar to what some of the accepted paradigm literature describes.

The question can be asked, how do new paradigm events correlate with the accepted geologic history timeline? First, the accepted geologic history timeline is based on both relative age dating and absolute age dating. Most relative ages are paradigm neutral and can be correlated with new paradigm events. Many absolute age dating techniques may be paradigm influenced and absolute ages have not been assigned to new paradigm events. In terms of relative age dates the major new paradigm change is movement of the Bell River drainage system formation time from a preglacial (and possibly middle Cenozoic) time to late 
during the first (Cenozoic) North American continental ice sheet's melt history. That change probably requires the first ice sheet's meltwater floods to have transported and deposited most continental United States Oligocene, Miocene, and Pliocene (and possibly some Eocene) sediments. In terms of absolute time the first ice sheet existed (probably with significant size and thickness variations) long enough to create and occupy its deep "hole" by raising mountain ranges and entire regions, although that length of time is not known. The linked second and thinner ice sheet, at least during its latest stage may correspond to what the accepted paradigm considers to be the Pleistocene. While the second ice sheet may have melted in ways that caused significant climatic variations, the two linked continental ice sheets appear to explain all detailed topographic map drainage system and erosional landform evidence.

\section{Analysis of the Two Competing Paradigms}

Perhaps the best way to compare two fundamentally different paradigms, which are at very different stages of development, and which have been developed by the using different types of evidence (without using one paradigm to judge the other) is to look at how well the paradigms address science research expectations These expectations require 1.) scientific work to be based on evidence visible to anyone willing to look, 2.) scientific work should use common sense logic at each step in the research process, 3.) scientific work should produce consistent and meaningful results, and 4.) when evidence can be explained in two or more ways (unless there is reason to believe otherwise) the simplest interpretation (or the interpretation requiring the fewest assumptions) is preferred. Another (and probably unachievable) expectation is all pertinent evidence should be addressed, which in this case neither paradigm has done. The accepted paradigm does not adequately address the well mapped drainage system and erosional landform evidence and the new paradigm, at least in its present stage of development, focuses almost entirely on the well-mapped drainage system and erosional landform evidence.

Looking at the first good science expectation the new paradigm relies on topographic maps now available to anyone who wants to look (at the USGS National Map website) and interprets drainage system and other erosional landform features, many of which are kilometers in length, although low points along drainage divides are critically important smaller features (which in some regions are identifiable by only one or two contour lines). USGS topographic maps may not show the most up-to-date cultural features, but the maps almost always correctly show kilometer long or longer drainage system and other erosional landform features and probably correctly show the smaller scale low points located along the much longer drainage divides. The new paradigm appears to address this first science research expectation.

The accepted paradigm relies on diverse types of evidence including geologic maps, fossils, and relative and absolute ages dates (other types of evidence are 
also used). Geologic maps show rock types and exposure locations and relative dating techniques suggest the sequence in which those rocks were formed. While geologic map quality varies, mapped rock types are usually found where shown and relative ages shown can be easily checked, so geologic maps usually address the first science research expectation. Fossils are real evidence and paleontologists usually correctly report where fossils were found (which can be checked by anyone willing to look). However, fossils need to be interpreted, which can mean placing the fossils in a sequence of faunal or floral succession and/or using the fossils to interpret a depositional environment. Such interpretations can be paradigm influenced and may or may not be made differently from a different paradigm's perspective. In other words, fossils address the first science research expectation to extent fossils exist and are usually found where reported to have been found, but may or may not satisfy that expectation when used as evidence of a rock unit's age or depositional environment. Many absolute age dates, especially radiometric age dates, like fossil interpretations, may be paradigm influenced and may or may not be interpreted the same way from a different paradigm's perspective.

Turning to the second science research expectation the new paradigm uses topographic map interpretation methods which consider low points along drainage divides (unless there is reason to think otherwise) to be places where a stream or river once flowed in one direction or the other across the drainage divide. Closely spaced low points along a drainage divide (especially if opposing valleys draining from those low points converge in downstream directions) can be considered possible evidence of a flood-formed converging and diverging channel complex that once crossed the drainage divide. When determining why a stream or river or diverging and converging channel complex no longer crosses the drainage divide the map interpretation methods look for logical explanations. For example, drainage divides following mountain range crests logically might have formed due to faster mountain range uplift than the valleys could be eroded. In other cases, topographic maps can be interpreted to show how headward erosion of a much deeper valley beheaded a stream, river, and/or diverging and converging channel complex and created the drainage divide by reversing the flow direction on the beheaded channel upstream end(s). Stream capture evidence in the form of barbed tributaries and abrupt drainage route direction changes is abundant on detailed topographic maps and while Bishop [38] argues beheading of drainage routes by the headward erosion of deeper valleys under normal conditions does not easily occur, the new paradigm describes large continental ice sheet meltwater floods that created the abnormal conditions needed to explain the abundant topographic map recorded stream capture events. The new paradigm expects common sense logic to be used during every research process step and appears to address the second science research expectation.

Almost all researchers following accepted paradigm rules believe they use 
common sense logic during each research process step, however much accepted paradigm research no longer starts with raw evidence (as new paradigm research has done to date), but is built on research done by others. Too often accepted paradigm research papers contain statements like this Syverson and Colgan ([39] p. 537) introduction that says "Wisconsin was probably glaciated dozens of times during the Pleistocene Epoch (2.58 - $0.012 \mathrm{Ma})$, but stratigraphical units provide direct evidence for at least four glaciations." The authors rely on information obtained from an uncited source that dozens of Pleistocene ice sheets may have reached into Wisconsin even though the statement requires a leap of faith because the authors admit they only can describe evidence for four such ice sheets. Reading further the authors go on to describe Early Pleistocene $(>781$ $\mathrm{Ma})$, Middle Pleistocene (320 - $128 \mathrm{Ma}$ ), and Late Pleistocene (31 - $17 \mathrm{Ma})$ sediment units associated with what the authors imply were at least three completely different continental ice sheets. While those described sediment units represent real evidence readers should take a moment and ask how reasonable is the implication that three or four completely independent continental ice sheets (separated by significant interglacial periods) reached into Wisconsin? Common sense logic suggests having three or four completely independent continental ice sheets occupying almost the same region of the North American continent, while perhaps possible, would be a remarkable coincidence. While the authors and the literature they cite present some evidence, that evidence like the Bell River drainage system evidence may be explainable in other ways. In other words, accepted paradigm research may not always be able to confirm that common sense logic was used at every step and may violate the second science research expectation.

Continuing to the third science research expectation, which is the results should tell a meaningful and consistent story, the new paradigm may have an advantage because to date it is has been developed by one researcher working with topographic maps. At least to the extent it has been developed the new paradigm enables researchers to interpret topographic map evidence so as to obtain results that fit together like picture puzzle pieces to tell a meaningful and consistent story, although that story is fundamentally different from the accepted paradigm Cenozoic geologic and glacial history story. Each of the new paradigm demonstration papers published to date, while addressing topographic map evidence taken from different and quite distinct northern Missouri River drainage basin geographic regions tells a story consistent with stories told by detailed topographic map evidence taken from the other different and distinct geographic regions. Compare that consistency with accepted paradigm consistency where researchers frequently tell different stories for the same evidence. In some examples Mears ([40], p. 609) in a literature review comments "A late Eocene age for the prominent sub-summit surface is the doctrine for most geologists in Colorado. However, dissenters in Wyoming consider the surface late Miocene," Fan et al. ([41], p. 547) suggest "When and how the central Rocky 
Mountains (Rockies) of western North America gained modern topography remain controversial questions" and McMillan et al. ([42], p. 393) report "Despite over a century of study, the timing and causes of the elevation gain and incision in the [Rocky Mountain] region are unclear.” A close reading of the published literature reveals the accepted paradigm does not enable researchers to always tell a meaningful and consistent Cenozoic geologic and glacial history story.

Lastly the fourth science expectation requires Occam's Razor to be used when two or more interpretations explain the same evidence. Occam's Razor, according to Anderson ([43], p. 57) says "what can be done with fewer [assumptions] is done in vain with more." As already described glacial histories determined from the accepted paradigm perspective claim there were at least four and maybe dozens of Cenozoic North American continental ice sheets while the analysis of drainage systems as shown on detailed topographic maps (using a new paradigm perspective) suggests two linked continental ice sheets probably explain all of the map evidence. Which paradigm perspective uses fewer assumptions and offers the simplest explanation? In terms of Rocky Mountain uplift and evolution Mears [40] summarizes accepted paradigm interpretations in a history that when following mid-Eocene deformation erosion lowered the mountain crests and (after some intervening late Eocene events) the eroded sediments and volcanic ash filled the valleys and intermontane basins and buried or partially buried the mountain ranges with Oligocene and Miocene sediments until mid-Miocene when regional uplift took place and exhumation of the mountain valleys and intermontane basins began. In contrast the new paradigm interpretation is Rocky Mountain and regional uplift occurred due to continental ice sheet related crustal warping while immense melt water floods flowed across and eroded the rising Rocky Mountain region. Again, which paradigm uses the fewest assumptions and describes the simplest history? Before answering that last question, a reader might remember geologic maps such as the Love and Christiansen [44] Geologic Map of Wyoming do not support a hypothesis that Oligocene and Miocene sediments once filled intermontane basins and buried or partially buried mountain ranges as Pelletier [45] and others claim. While from the accepted paradigm perspective a relationship between continental ice sheets and regional and Rocky Mountain uplift is usually not reported, glacial isostatic adjustment is well-documented with Sella et al. [46], for example, reporting present-day uplift of about $10 \mathrm{~mm}$ per year near the now ice sheet free Hudson Bay region.

\section{Discussion and Conclusion}

The accepted North American Cenozoic geologic and glacial history paradigm is like a tall building still under construction. Construction started many decades ago and today almost all work is taking place on upper levels where additional floors are being added with newly built rooms being finished, sometimes with excellent workmanship and in elaborate detail. However, no one appears to be checking to determine whether the building foundation (set in place many years 
ago) is solid or to see if what are sometimes conflicting designs permit hallways, staircases, and elevator shafts to connect as they should. In addition, lying in the weeds some distance away and almost forgotten about are the solid foundation stones (the ignored drainage system and erosional landform topographic map evidence) that should be in the foundation supporting the building. The time is coming when those solid foundation stones will need to replace flawed foundation stones upon which the building now rests and when that time comes, the building may have to be torn down and then reconstructed with the discarded and more solid foundation stones at its base.

Kuhn [6] describes a paradigm as being a set of rules enabling scientists to explain evidence (to finish rooms in the tall building analogy) and to find new research opportunities (to add new floors on top of the building), but also with the ability to identify anomalous evidence the paradigm cannot explain or explain well (the discarded and forgotten about and ignored drainage system and erosional landform topographic map evidence). As described geomorphologists working from the accepted paradigm perspective are unable to satisfactorily explain much of the topographic map drainage system and erosional landform evidence and for that reason many no longer try to do so. Drainage systems and erosional landforms are large-scale features found almost everywhere and any Cenozoic geologic and glacial history must satisfactorily explain them. Yet, like in the above tall building analogy builders of the accepted North American Cenozoic geologic and glacial history paradigm discarded and have forgotten about the detailed topographic map drainage system and erosional landform evidence. Without that solid foundation, the accepted North American Cenozoic geologic and glacial history paradigm rests on foundation stones like the hypothesized Bell River drainage system "pre-glacial" age and the remarkable coincidence that multiple and independent continental ice sheets expanded into almost identical regions of the North American continent.

In conclusion, anomalous evidence can threaten any scientific paradigm, and in this case well-mapped anomalous drainage system and erosional landform evidence threatens the accepted Cenozoic geologic and glacial history paradigm. That accepted paradigm requires the north-oriented Bell River drainage system to have formed in preglacial (middle Cenozoic time), but is unable to satisfactorily explain much of the northern Missouri River drainage basin detailed topographic map drainage system and erosional landform evidence. A new paradigm has emerged, which can explain northern Missouri River drainage basin detailed topographic map drainage system and erosional landform evidence, and which requires the north-oriented Bell River drainage system to have formed late during a continental ice sheet's melt history and which leads to a fundamentally different northern Missouri River drainage basin middle and late Cenozoic geology and glacial history than the accepted paradigm describes. The new paradigm appears to meet good science research expectations by being based on evidence anyone can observe, by requiring each research step to use common sense logic, 
by producing meaningful and consistent results, and by offering simpler explanations than the accepted paradigm appears to offer. New paradigm research is still in its infancy and further work is needed to demonstrate the new paradigm's ability to explain drainage system and erosional landform evidence located in other geographic regions, including in the Ohio River drainage basin.

\section{Acknowledgements}

Preliminary work leading to the new paradigm development was done while employed as a Minot State University faculty member. The author thanks Arthur Strahler (then at Columbia University) and Brainerd "Nip" Mears, Jr. (then at the University of Wyoming) for introducing numerous unsolved regional drainage history problems.

\section{Conflicts of Interest}

The author declares no conflicts of interest regarding the publication of this paper.

\section{References}

[1] Fenneman, N.M. (1931) Physiography of Western United States. McGraw-Hill Book Company, Inc., New York, 534 p.

[2] Fenneman, N.M. (1938) Physiography of Eastern United States. McGraw-Hill Book Company, Inc., New York, 714 p.

[3] Thornbury, W.D. (1965) Regional geomorphology of the United States. John Wiley and Sons, Inc., New York, 609 p.

[4] Strahler, A.N. (1945) Hypotheses of Stream Development in the Folded Appalachians of Pennsylvania. Geological Society of America Bulletin. 56, 45-88. https://doi.org/10.1130/0016-7606(1945)56[45:HOSDIT]2.0.CO;2

[5] Strahler, A.N. (1952) Dynamic Basis of Geomorphology. Bulletin of the Geological Society of America, 63, 923-938. https://doi.org/10.1130/0016-7606(1952)63[923:DBOG]2.0.CO;2

[6] Kuhn, T.S. (1970) The Structure of Scientific Revolutions. Second Edition, Enlarged. The University of Chicago Press, Chicago, $210 \mathrm{p}$.

[7] McMillan, J.N. (1973) Shelves of the Labrador Sea and Baffin Bay, Canada. Canadian Society of Petroleum Geologists Memoir, 1, 473-515.

[8] Duk-Rodkin, A. and Hughes, O.L. (1994) Tertiary-Quaternary Drainage of the Pre-Glacial MacKenzie River Basin. Quaternary International, 22-23, 221-241. https://doi.org/10.1016/1040-6182(94)90015-9

[9] Jackson, L. (2018) The Paleo-Bell River: North America's Vanished Amazon. Earth, 63, 74-81.

[10] Sears, J.W. (2013) Late Oligocene-Early Miocene Grand Canyon: A Canadian Connection? GSA Today, 23, 4-10. https://doi.org/10.1130/GSATG178A.1

[11] White, W.A. (1972) Deep Erosion by Continental Ice Sheets. Geological Society of America Bulletin, 83, 1037-1056. https://doi.org/10.1130/0016-7606(1972)83[1037:DEBCIS]2.0.CO;2

[12] White, W.A. (1988) More on Deep Glacial Erosion by Continental Ice Sheets and 
Their Tongues of Distributary Ice. Quaternary Research, 30, 137-150. https://doi.org/10.1016/0033-5894(88)90019-1

[13] Gravenor, C.P. (1975) Erosion by Continental Ice Sheets. American Journal of Science, 275, 594-604. https://doi.org/10.2475/ajs.275.5.594

[14] Sugden, D.E. (1976) A Case against Deep Erosion of Shields by Continental Ice Sheets. Geology, 4, 580-582.

https://doi.org/10.1130/0091-7613(1976)4<580:ACADEO>2.0.CO;2

[15] Russell, W.L. (1929) Drainage Alignment in the Western Great Plains. The Journal of Geology, 37, 249-255. https://doi.org/10.1086/623618

[16] White, E.M. (1961) Drainage Alignment in Western South Dakota. American Journal of Science, 259, 207-210. https://doi.org/10.2475/ajs.259.3.207

[17] Shurr, G.W. (1982) Geological Significance of Lineaments Interpreted from Landsat Images near the Northern Black Hills. In: Christopher, J.E. and Kaldi, J., Eds., 4th International Williston Basin Symposium, North Dakota Geological Society and Saskatchewan Geological Society, Regina, 313-320.

[18] Clayton, L., Moran, S.R. and Bluemle, J.P. (1980) Geologic Map of North Dakota. United States Geologic Survey, Reston, Scale: 1:500,000.

[19] Flint, R.F. (1955) Pleistocene Geology of Eastern South Dakota. Professional Paper 262, United States Geological Survey, Reston, 174 p. https://doi.org/10.3133/pp262

[20] Clausen, E. (2017) Using Map Interpretation Techniques for Relative Dating of a Western North Dakota and South Dakota Drainage Basin Formation Sequence, Missouri River Drainage Basin, USA. Journal of Geography and Geology, 9, 1-18. https://doi.org/10.5539/jgg.v9n4p1

[21] Clausen, E. (2019) Origin of the Redwater River Drainage Basin Determined by Topographic Map Interpretation: Eastern Montana, USA. Journal of Geography and Geology, 11, 42-54. https://doi.org/10.5539/jgg.v11n1p42

[22] Clausen, E. (2019) How a Fundamentally Different and New Glacial History Paradigm Explains North America Glaciated Prairie Region Erosional Escarpments and Drainage Patterns. Earth Science Research, 8, 23-34.

[23] Clausen, E. (2020) Topographic Map Analysis of Mountain Passes Crossing the Continental Divide between Colorado River Headwaters and North and South Platte River Headwaters to Test a New Geomorphology Paradigm. Journal of Geography and Geology, 12, 50-64. https://doi.org/10.5539/jgg.v12n1p50

[24] Clausen, E. (2020) Use of Topographic Map Evidence from Drainage Divides Surrounding Wyoming's Great Divide Basin to Compare Two Fundamentally Different Regional Geomorphology Paradigms. Earth Science Research, 9, 45-57.

[25] Clausen, E. (2018) Topographic Map Analysis of High Elevation Black Hills through Valleys Linking Spearfish and Rapid Creek Headwaters Valleys, Lawrence County, South Dakota, USA. Journal of Geography and Geology, 10, 8-21.

http://www.ccsenet.org/journal/index.php/jgg/article/view/72098 https://doi.org/10.5539/jgg.v10n1p8

[26] Clausen, E. (2017) Solving a Perplexing Scenic and Sage Creek Drainage History Problem, Pennington County, South Dakota, USA. Journal of Geography and Geology, 9, 1-10. https://doi.org/10.5539/jgg.v9n2p1

[27] Clausen, E. (2018) Belle Fourche River-Cheyenne River Drainage Divide Area in the Wyoming Powder River Basin Analyzed by Topographic Map Interpretation Methods, USA. Journal of Geography and Geology, 10, 1-16.

https://doi.org/10.5539/jgg.v10n2p1 
[28] Todd, J.E. (1902) Hydrographic History of South Dakota. Geological Society of America Bulletin, 13, 27-40. https://doi.org/10.1130/GSAB-13-27

[29] Harksen, J.C. (1966) The Pliocene-Pleistocene Medicine Root Gravel of Southwestern South Dakota. Bulletin of the Southern California Academy of Sciences, 65, 251-257.http://www.sdgs.usd.edu/pubs/pdf/NR-09.pdf

[30] Zaprowski, B.J., Evenson, E.B., Pazzaglia, F.J. and Epstein, J.B. (2001) Knickzone Propagation in the Black Hills and Northern High Plains: A Different Perspective on the Late Cenozoic Exhumation of the Laramide Rocky Mountains. Geology, 29, 547-550. https://doi.org/10.1130/0091-7613(2001)029<0547:kpitbh>2.0.co;2

[31] Stamm, J.F., Hendricks, R.R., Sawyer, J.F., Mahan, S.A., Zaprowski, B.J., Geibel, N.M. and Azzolimi, D.C. (2013) Late Quaternary Stream Piracy and Strath Terrace Formation along the Belle Fourche and Lower Cheyenne Rivers, South Dakota and Wyoming. Geomorphology, 197, 10-20. https://doi.org/10.1016/j.geomorph.2013.03.028

[32] Straffin, E.C. (1993) Alluvial Terrace Development in the Southeastern Black Hills of South Dakota. Northern Arizona University, Flagstaff, 91 p.

[33] Clausen, E. (2017) Origin of Little Missouri River-South Fork Grand River and Nearby Drainage Divides in Harding County, South Dakota and Adjacent Eastern Montana, USA. Open Journal of Geology, 7, 1063-1077. https://doi.org/10.4236/ojg.2017.78071

[34] Toepelman, W.C. (1925) The Geology of a Portion of the Slim Buttes Region of Northwestern South Dakota, with Special Reference to Unusual Structural Features due to Slumping. University of Chicago, Chicago, $76 \mathrm{p}$.

[35] Gill, J.R. (1962) Tertiary Landslides, Northwestern South Dakota and Southeastern Montana. Geological Society of America Bulletin, 73, 725-735. https://doi.org/10.1130/0016-7606(1962)73[725:TLNSDA]2.0.CO;2

[36] Lillegraven, J.A. (1970) Stratigraphy, Structure, and Vertebrate Fossils of the Oligocene Brule Formation, Slim Buttes, Northwestern South Dakota. Geological Society of America Bulletin, 81, 831-850.

https://doi.org/10.1130/0016-7606(1970)81[831:SSAVFO]2.0.CO;2

[37] Clausen, E. (1989) Presence of Rounded Boulders and Large Cobbles at Base of White River Group (Oligocene) Strata in Southwest North Dakota and northwest South Dakota. Contributions to Geology, University of Wyoming, 27, 1-6.

[38] Bishop, P. (1995) Drainage Rearrangement by River Capture, Beheading and Diversion. Progress in Physical Geography, 19, 449-473. https://doi.org/10.1177/030913339501900402

[39] Syverson, K.M. and Colgan, P.M. (2011) Chapter 42: The Quaternary of Wisconsin: An Updated Review of Stratigraphy, Glacial History and Landforms. In: Ehlers, J., Gibbard, P.L. and Hughes, P.D., Eds., Developments in Quaternary Science, Vol. 15, 537-552. https://doi.org/10.1016/B978-0-444-53447-7.00042-8

[40] Mears Jr., B. (1993) Geomorphic History of Wyoming and High-Level Erosion Surfaces. In: Snoke, A.W., et al., Eds., Geology of Wyoming, Geological Survey Wyoming, Laramie, Memoir, No. 5, 608-626.

[41] Fan, M., Heller, P., Allen, S.D. and Hough, B.G. (2014) Middle Cenozoic Uplift and Concomitant Drying in the Central Rock Mountains and Adjacent Great Plains. Geology, 42, 547-550. https://doi.org/10.1130/G35444.1

[42] McMillan, M.E., Heller, P.L. and Wing, S.L. (2006) History and Causes of Post-Laramide Relief in the Rocky Mountain Orogenic Plateau. Geological Society of America Bulletin, 118, 393-405. https://doi.org/10.1130/B25712.1 
[43] Anderson, D.L. (2002) Occam's Razor: Simplicity, Complexity, and Global Dynamics. Proceeding of the American Philosophical Society, 146, 56-76.

[44] Love, J.D. and Christiansen, A.C. (1985) Geologic Map of Wyoming. United States Geological Survey, Reston, Scale 1:500,000.

[45] Pelletier, J.D. (2009) The Impact of Snowmelt on the Late Cenozoic Landscape of the Southern Rocky Mountains, USA. GSA Today, 19, 4-11.

https://doi.org/10.1130/GSATG44A.1

[46] Sella, G.F., Stein, S., Dixon, T.H., Craymer, M., James, T.S., Mazzotti, S. and Dokka, R.K. (2007) Observation of Glacial Isostatic Adjustment in "Stable" North America with GPS. Geophysical Research Letters, 34, Article ID: L02306.

https://doi.org/10.1029/2006GL027081 